\title{
PENGARUH MEDIA PEMBELAJARAN VIDEO TUTORIAL MYOB DAN KEMANDIRIAN BELAJAR TERHADAP HASIL BELAJAR AKUNTANSI KOMPUTER KELAS XI SMK NEGERI 1 RANGKASBITUNG
}

\author{
Otong Hidayat \\ SMKN 1 Rangkasbitung \\ Rangkasbitung, Indonesia \\ otonghidayat1402@gmail.com
}

\begin{abstract}
This study aims to knowing the difference between computer accounting learning outcomes of students who learn to used MYOB video tutorials and students who learn to used power point And the difference between learning outcomes of students who have high learning independence and low independence. In addition, this research aims to determine the effect of video tutorial interactions and learning independence. The results show that there is a difference in learning outcomes of $12.35 \%$ who learn used video tutorials and those who learn using power point. In addition, there is a difference in learning outcomes of 7.63\%, students who have high learning independence and students who have low learning independence and there is an influence of video tutorial interactions and learning independence.
\end{abstract}

Keyword: $M Y O B$ Video Tutorial, Learning Independence and Computer Accounting Learning Outcomes

\section{PENDAHULUAN}

Pelaksanaan pembelajaran di SMK dinyatakan optimal, apabila terdapat kesesuaian antara kualitas lulusan SMK dengan kebutuhan lapangan kerja/industri yang pada akhirnya dapat menigkatkan kualitas lulusan SMK. Namun pada pembelajaran di SMK belum dapat dilaksananakan secara optimal. Berdasarkan hasil belajar siswa yang terlihat dari rendahnya hasil belajar yang dicapai oleh para peserta didik. Rendahnya hasil belajar siswa mengakibatkan banyak lulusan SMK yang tidak terserap di lapangan pekerjaan yang sesuai dengan bidang keahliannya. Kondisi yang seperti itu juga terjadi kepada siswa di SMK Negeri 1 Rangkasbitung. Hal tersebut merupakan bagian dari faktor-faktor yang mempengaruhi di dalam proses pembelajaran di sekolah. Pada dasarnya faktor-faktor yang mempengaruhi hasil belajar peserta didik dipengaruhi oleh dua faktor, yaitu faktor internal dan faktor eksternal, faktor internal berupa minat, motivasi dan perhatian maupun faktor eksternal berupa metode mengajar, media 
pembelajaran dan lingkungan sosial berpengaruh terhadap hasil belajar. (Kurniawan et al., 2018) Apabila dengan mengupayakan faktor-faktor tersebut dengan mengoptimalkan fungsinya diharapkan akan meningkatkan hasil belajar peserta didik.

Media memberikan dampak yang berbeda-beda pada proses pembelajaran. Tergantung bagaimana penggunaanya. (Daheri et al., 2020) Dengan menggunakan media pembelajaran yang menarik dan efektif, sehingga siswa tertarik dan termotivasi dalam proses pembelajaran yang sedang berlangsung.(Fadillah, 2018)

Mind Your Own Business (MYOB) merupakan program akuntansi berbasis komputer yang paling populer.(Safitri \& Setiyani, 2016) Dalam MYOB peserta didik diberikan kemudahan dalam membuat jurnal, buku besar, laporan keuangan, ataupun yang lainnya dengan menggunakan kertas kerja.

Video tutorial merupakan salah satu video yang dibuat untuk mempermudah peserta didik dalam merupakan sikap pribadi yang sangat diperlukan oleh setiap peserta didik. Kemandirian belajar merupakan keharusan dalam proses pembelajaran dewasa ini, sejauh pelajaran itu diarahkan kepada hari depan siswa, yang dengan nyata dapat dilihat dalam keluarga dan masyarakat. (Rijal \& Bachtiar, 2015)
Peserta didik mempunyai kemandirian belajar apabila muncul keinginannya sendiri untuk belajar akuntansi, dan mampu memecahkan proses pembelajaran akuntansi secara mandiri. Ada pengaruh positif dan signifikan secara parsial pembentukan karakter bertanggung jawab terhadap hasil belajar ekonomi materi persamaan dasar akuntansi. Secara simultan pembentukan karakter disiplin dan bertanggung jawab berpengaruh signifikan terhadap hasil belajar.(Budiani \& Sholikhah, 2020) menggunakan aplikasi MYOB yang akan memandu peserta didik dalam menggunakan aplikasi MYOB tersebut setahap demi setahap sampai siklus akuntansi selesai. Selain menggunakan media pembelajaran, kemandirian belajar juga sangat berpengaruh terhadap hasil belajar siswa.

Tujuan penelitian ini adalah membuat evaluasi Perbedaan hasil belajar akuntansi komputer antara peserta didik yang dibelajarkan menggunakan media video tutorial $M Y O B$ dan media microsoft power point, Perbedaan hasil belajar peserta didik dengan kemandirian belajar tinggi dan peserta didik dengan kemandirian belajar rendah serta Pengaruh interaksi antara media pembelajaran dan kemandirian belajar terhadap hasil belajar mata pelajaran akuntansi komputer. 


\section{METHOD}

Penelitian ini dilakukan di SMK Negeri 1 Rangkasbitung beralamat di Jalan Dewi Sartika No 61.L Kelurahan Muara Ciujung Timur Kecamatan Rangkasbitung. Penelitian ini dilaksanakan pada semester genap tahun pelajaran 2019-2020. Waktu pelaksanaan penelitian ini direncanakan akan dilaksanakan pada bulan Februari sampai dengan bulan Juni 2020.

Penelitian ini menggunakan metode penelitian "quasi eksperiment" atau eksperimen semu dengan desain nonequivalent kontrol group. Quasi eksperimen hampir sama dengan eksperimen sebenarnya. Perbedaannya pada penggunaan subyek yaitu pada kuasi eksperimen tidak dilakukan penugasan random melainkan menggunakan kelompok yang ada.(Lestari, 2017) Metode ini memungkinkan peneliti mengendalikan variabel sebanyak mungkin dari situasi yang ada. Design ini yaitu mengendalikan variabel secara penuh seperti pada eksperimen keadaan sebenarnya, namun peneliti bisa memperhitungkan variabel apa saja yang tidak mungkin dikendalikan dalam mengintepretasikan hasil penelitian. Penelitian ini dilakukan dengan membandingkan dua jenis media pembelajaran yaitu video tutorial $M Y O B$ dengan media microsoft power point yang dikaitkan dengan kemandirian belajar tinggi dan kemandirian belajar rendah.

Adapun variabel dalam penelitian ini terdiri dari dua variabel bebas dan satu variabel terikat.

1. Variabel bebas pertama adalah (A) media pembelajaran yang terdiri dari $\left(\mathrm{A}_{1}\right)$ media video tutorial $M Y O B$ dan $\left(\mathrm{A}_{2}\right)$ media microsoft power point. Sedangkan variabel bebas kedua adalah (B) kemandirian belajar yang dibedakan antara $\left(B_{1}\right)$ kemandirian belajar tinggi dan $\left(B_{2}\right)$ kemandirian belajar rendah.

2. Variabel terikat adalah hasil belajar akuntansi komputer materi input account.

Penelitian ini menggunakan desain faktorial $2 \times 2$ seperti yang disajikan pada tabel berikut:

Tabel 1

Desain Faktorial

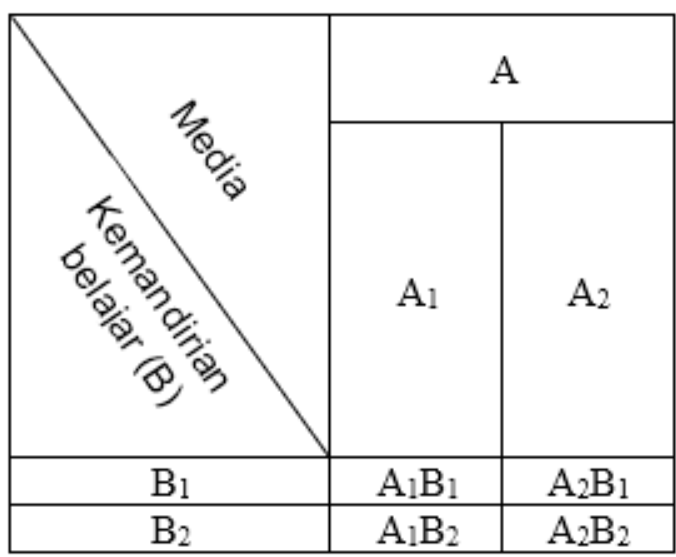

Keterangan:

Variabel terikat Y : Hasil belajar peserta 
didik

Variabel bebas A :Media Pembelajaran

$\mathrm{A}_{1} \quad$ : video tutorial MYOB

$\mathrm{A}_{2}$ : microsoft power point

Variabel bebas B : Kemandirian belajar

$\mathrm{B}_{1}$ : Kemandirian belajar tinggi

$\mathrm{B}_{2}$ : Kemandirian belajar rendah

$\mathrm{A}_{1} \mathrm{~B}_{1}=$ Skor hasil belajar kelompok kemandirian belajar tinggi pada pelajaran Akuntansi Komputer yang dibelajarkan menggunakan media video tutorial $M Y O B$

$\mathrm{A}_{2} \mathrm{~B}_{1}=$ Skor hasil belajar kelompok kemandirian belajar tinggi pada pelajaran Akuntansi komputer yang dibelajarkan menggunakan media microsoft power point

$\mathrm{A}_{1} \mathrm{~B}_{2}=$ Skor hasil belajar dengan kelompok kemandirian belajar rendah pada pelajaran Akuntansi Komputer yang dibelajarkan dengan menggunakan media video tutorial $M Y O B$

$\mathrm{A}_{2} \mathrm{~B}_{2}=$ Skor hasil belajar dengan kelompok kemandirian belajar rendah pada pelajaran Akuntansi Komputer yang dibelajarkan dengan menggunakan media microsoft power point.

\section{HASIL DAN PEMBAHASAN}

Data yang dianalisis pada penelitian ini adalah data dari peserta didik yang menjadi responden skor hasil belajar peserta didik tentang cara pembuatan daftar akun dan pengisian saldo awal akun buku besar perusahaan dagang pada mata pelajaran komputer akuntansi semester genap dengan menggunakan media video tutorial dan media power point. Data diolah dengan menggunakan bantuan software SPSS sedangkan data penelitian ini bersumber dari data kelas eksperimen dan kelas kontrol. Perolehan nilai terdiri dari: 1) nilai hasil pretest kelas eksperimen dan

kelas kontrol; 2) nilai hasil post test kelas ekperimen dan kelas kontrol; 3) Skor hasil angket kemandirian belajar peserta didik pada kelas experimen dan kelas kontrol.

Penggunaan statistik dalam penelitian ini untuk menguji pengaruh penggunaan media pembelajaran video tutorial MYOB dan kemandirian belajar peserta didik terhadap hasil belajar akuntansi komputer kelas XI di SMKN 1 Rangkasbitung.

Data penelitian ini yang dideskripsikan pada bab ini berkaitan dengan pembelajaran menggunakan media video tutorial $\left(\mathrm{X}_{1}\right)$ dan kemandirian belajar peserta didik $\left(\mathrm{X}_{2}\right)$ terhadap hasil belajar akuntansi komputer (Y). Dalam bab ini terdiri dari empat bagian. Pertama, bagian deskripsi data, kedua pengujian persyaratan analisis, ketiga pengujian hipotesis dan keempat pembahasan hasil penelitian.

Penelitian eksperimen ini menggunakan desain factorial 2X2 dengan 
analisis data menggunakan ANAVA dua jalur, sementara pengelolaan data menggunakan bantuan program SPSS.

Data hasil belajar akuntansi komputer ini disajikan dalam beberapa kelompok yaitu: (1) Data hasil belajar akuntansi komputer yang menggunakan media pembelajaran video tutorial $\left(\mathrm{A}_{1}\right) ;(2)$ Data hasil belajar akuntansi komputer yang menggunakan media pembelajaran power point $\left(\mathrm{A}_{2}\right)$; (3) data hasil belajar akuntansi komputer yang memiliki kemandirian belajar tinggi (B1); (4) Data hasil belajar akuntansi komputer yang memiliki kemandirian belajar rendah (B2); untuk mengetahui lebih rincian data tersebut dapat dilihat pada table berikut ini :

Tabel 2. Rekapitulasi Hasil Belajar Akuntansi Komputer

\begin{tabular}{lllllll}
\hline Kel & N & Min & Max & Mean & $\begin{array}{l}\text { Stan } \\
\text { Dev }\end{array}$ & Variance \\
\hline A1 & $\mathbf{2 2}$ & $\mathbf{6 5 , 0 0}$ & $\mathbf{9 5 , 0 0}$ & $\mathbf{8 1 , 1 4}$ & $\mathbf{8 , 0 1}$ & $\mathbf{6 4 , 1 2}$ \\
A2 & $\mathbf{2 2}$ & $\mathbf{6 0 , 0 0}$ & $\mathbf{8 5 , 0 0}$ & $\mathbf{7 5 , 6 8}$ & $\mathbf{5 , 6 3}$ & $\mathbf{3 1 , 6 6}$ \\
B1 & $\mathbf{2 2}$ & $\mathbf{8 9 , 0 0}$ & $\mathbf{1 3 7 , 0 0}$ & $\mathbf{1 1 2 , 5 5}$ & $\mathbf{1 4 , 7 3}$ & $\mathbf{2 1 6 , 8 3}$ \\
B2 & $\mathbf{2 2}$ & $\mathbf{8 5}$ & $\mathbf{1 2 6 , 0 0}$ & $\mathbf{1 0 3 , 9 5}$ & $\mathbf{1 3 , 8 1}$ & $\mathbf{1 9 0 , 7 1}$ \\
\hline
\end{tabular}

( Data yang diolah, 2020)

1. Perbedaan hasil belajar Akuntansi Komputer peserta didik antara kelompok peserta didik yang dibelajarkan menggunakan media video tutorial MYOB dengan peserta didik yang dibelajarkan menggunakan pembelajaran dengan media power point $\left(\mathrm{A}_{1}\right.$ dan $\left.\mathrm{A}_{2}\right)$. Pemberian perlakuan pada kelas eksperimen dengan media video tutorial MYOB dan pada kelas kontrol dibelajarkan menggunakan media power point menunjukkan temuan adanya perbedaan hasil belajar akuntansi komputer, peserta didik yang diberikan perlakuan dengan media video tutorial MYOB rerata hasil belajarnya lebih tinggi $12.35 \%$ dibanding dengan peserta didik yang diberi perlakuan dengan media power point, hal ini sejalan dengan temuan penelitian Muliana. Hasil penelitian menunjukkan bahwa hasil belajar peserta didik yang dibelajarkan dengan menggunakan media pembelajaran video tutorial rata-rata berada pada kategori tinggi, sedangkan hasil belajar peserta didik yang dibelajarkan tanpa menggunakan media pembelajaran video tutorial berada pada kategori cukup.

Video tutorial adalah suatu rangkaian gambar hidup (video) yang ditayangkan oleh seorang pengajar yang berisi materi pembelajaran untuk membantu pemahaman terhadap suatu materi pembelajaran sebagai media bimbingan atau bahan pengajaran tambahan kepada sekelompok kecil peserta didik.

Media video tutorial dapat mempengaruhi kemandirian dan hasil belajar peserta didik.(Kusnadi et al., 2018) Begitu juga dengan penggunaan media power point, hanya saja media video tutorial MYOB lebih besar memberikan pengaruhnya. Media tutorial Myob merupakan sarana 
media pembelajaran yang sangat membantu untuk peserta didik dalam menguasai akuntansi berbasis komputer karena menjelaskan secara rinci tahapantahapannya pembuatannya sehingga peserta didik mudah mengikuti Langkahlangkahnya.

2. Perbedaan hasil belajar Akuntansi Komputer peserta didik antara kelompok peserta didik yang memiliki kemandirian belajar tinggi dan kemandirian belajar rendah $\left(\mathrm{B}_{1}\right.$ dan $\left.\mathrm{B}_{2}\right)$. Berdasarkan hasil penelitian ini ditemukan hasil belajar akuntansi komputer peserta didik yang memiliki kemandirian belajar tinggi mendapatkan hasil belajar lebih tinggi 7.63\% dibandingkan dengan hasil belajar akuntansi komputer peserta didik yang memiliki kemandirian belajar rendah, karena kemandirian merupakan sikap pribadi yang sangat diperlukan untuk setiap peserta didik. Kemandirian belajar siswa sebagai suatu kegiatan yang berasal dari kemampuan diri sendiri, belajar yang mandiri dan tidak tergantung terhadap orang lain serta bertanggungjawab agar tercapainya tujuan yang diinginkan.(Nurfadilah \& Hakim, 2019)

Temuan ini sejalan dengan penelitian(Ningsih \& Nurrahmah, 2016) Kemandirian belajar adalah kondisi aktivitas belajar yang mandiri tidak bergantung pada orang lain, memiliki kemauan serta tanggung jawab sendiri dalam menyelesaikan masalah belajarnya. Kemandirian belajar akan terwujud apabila peserta didik aktif mengontrol sendiri segala sesuatu yang dikerjakan, mengevaluasi dan selanjutnya merencanakan sesuatu yang lebih dalam pembelajarannya dan peserta didik juga mau aktif dalam proses pembelajaran.

Peserta didik yang memiliki kemandirian belajar yang tinggi akan dapat mencerna pelajaran sendiri dan dengan cara belajar sendiri pada waktu yang dipilihnya sendiri tanpa bimbingan dan tatap muka dengan guru. Mereka dapat memilih dan menentukan materi pelajaran yang diperlukannya. Berbeda dengan peserta didik yang memiliki kemandirian belajar yang rendah, mereka membutuhkan bimbingan dan arahan guru untuk dapat memahami pelajaran. Kemandirian belajar peserta didik dapat terlihat pada kebiasaan-kebiasaan dalam belajar sehari-hari seperti cara peserta didik merencanakan dan melakukan pembelajaran.

3. Pegaruh interaksi antara media pembelajaran dengan kemandirian belajar belajar peserta didik terhadap hasil belajar Akuntansi Komputer (A dan B). 
Bertitik tolak dari hasil pengujian pengaruh interaksi penggunaan media video tutorial MYOB dan kemandirian belajar teradap hasil belajar peserta didik, mununjukkan terdapat pengaruh interaksi antara penggunaan media tutorial dan kemandirian belajar terhadap hasil belajar peserta didik. Dengan adanya interaksi ini, maka peserta didik yang memiliki kemandirian belajar tinggi cocok/tepat bila pembelajarannya menggunakan media video tutorial sehingga hasil belajarnya akan tinggi. Berbeda halnya dengan peserta didik yang memiliki kemandirian belajar randah akan lebih tepat bila guru menggunakan media power point.

Temuan ini sejalan dengan penelitian(Mema, 2016) Kemandirin belajar merupakan suatu kondisi aktivitas belajar mandiri yang tidak tergantung pada orang lain, memiliki kemauan dan bertanggung jawab sendiri dalam menyelesaikan masalah. Kemandirian saat belajar akan terwujud apabila peserta didik aktif belajar sendiri dan mengontrol segala sesuatu yang dikerjakan, mengevaluasi serta selanjutnya merencanakan sesuatu lebih dalam pada saat pembelajaran yang dilalui dan peserta didik juga mau aktif dalam proses pembelajaran.
Peserta didik yang memiliki kemandirian yang tinggi akan dapat mencerna pelajaran sendiri dan dengan cara belajar sendiri pada waktu yang dipilihnya sendiri tanpa bimbingan dan tatap muka dengan guru. Berbeda halnya dengan peserta didik yang memiliki kemandirian belajar rendah, merak membutuhkan bimbingan dan arahan guru untuk dapat memahami materi pembelajaran. Kemandirian belajar pada peserta didik dapat dilihat pada kebiasaaan-kebiasaan belajar peserta didik sehari-hari seperti cara peserta didik merencanakan dan melakukan pembelajaran.

\section{KESIMPULAN}

\section{A. Kesimpulan}

1.Terdapat perbedaan hasil belajar akuntansi komputer antara peserta didik yang pembelajarannya menggunakan media video tutorial MYOB dan Media power point. Hasil belajar peserta didik yang menggunakan media video tutorial MYOB lebih tinggi $12,35 \%$ hasil belajarnya dari pada peserta didik yang menggunakan media power point $M Y O B$.

2.Terdapat perbedaan hasil belajar akuntansi komputer antara peserta didik yang memiliki kemandiriian belajar tinggi dan peserta didik yang memiliki kemandirian belajar rendah. Hasil belajar yang memiliki kemandirian belajar tinggi lebih 
tinggi 7,63\% dari pada perserta didik yang memiliki kemandirian belajar rendah.

3.Terdapat pengaruh interaksi antara penggunaan media media pembelajaran dengan kemandirian belajar peserta didik. Peserta didik yang memiliki kebiasaan kemandirian belajar tinggi lebih tepat menggunakan media video tutorial MYOB untuk meningkatkan hasil belajarnya, sedangkan peserta didik yang memiliki kemandirian belajar lebih rendah lebih tepat menggunakan media power point untuk meningkatkan hasil belajarnya.

\section{B.Saran}

Adapun rekomendasi untuk pemanfaatan produk ini yaitu:

1.Penelitian ini terbatas pada mata pelajaran akuntansi komputer di kelas XI Akuntansi dan Keuangan Lembaga. Maka disarankan pada peneliti lain agar menerapkan media video tutorial pada perusahan manufaktur.

2.Sebaiknya setiap sekolah kejuruan memberikan fasilitas laboratorium komputer yang memadai agar pembelajaran akuntansi komputer di sekolah dapat berjalan dengan baik dan optimal.

3.Sebaiknya guru meningkatkan keterampilan menjelaskan dan menggunakan berbagai macam media pembelajaran serta mampu memilih media yang sesuai untuk peserta didik.

\section{REFERENCES}

Budiani, \& Sholikhah, N. (2020). Pengaruh Pembentukan Karakter Disiplin Dan Tanggung Jawab Terhadap Hasil Belajar Ekonomi Persamaan Dasar Akuntansi. Jurnal Pendidikan Karakter, 2, 263-271.

Daheri, M., Juliana, J., Deriwanto, D., \& Amda, A. D. (2020). Efektifitas WhatsApp sebagai Media Belajar Daring. Jurnal Basicedu, 4(4), 775783.

https://doi.org/10.31004/basicedu.v4i4 .445

Fadillah, A. (2018). Pengembangan Media Belajar Komik Terhadap Motivasi Belajar Siswa. JTAM | Jurnal Teori Dan Aplikasi Matematika, 2(1), 36. https://doi.org/10.31764/jtam.v2i1.259

Kurniawan, B., Wiharna, O., \& Permana, T. (2018). Studi Analisis Faktor-Faktor yang Mempengaruhi Hasil Belajar pada Mata Pelajaran Teknik Listrik Dasar Otomotif. Journal of Mechanical Engineering Education, 4(2), 156. https://doi.org/10.17509/jmee.v4i2.962 7

Kusnadi, H. K., Hidayat, A., \& Mariam, P. (2018). Penggunaan Media Pembelajaran Video Tutorial dalam Upaya Meningkatkan Kemandirian Belajar Peserta Didik. Jurnal Pendidikan Dan Pembelajaran Ekonomi Akuntansi, 4(1), 1-8. http://jurnal.fkip.unla.ac.id/index.php/j p2ea/article/view/307

Lestari, A. F. (2017). MENINGKATKAN KEMAMPUAN PEMAHAMAN MATEMATIS SISWA MELALUI MODEL PROBLEM BASED LEARNING (PBL) (Penelitian Quasi Eksperimen terhadap Siswa SMP Negeri 1 Tambakdahan). BIORMATIKA Jurnal Ilmiah FKIP 
Universitas Subang, 3(1).

Mema, N. (2016). Kemandirian Dan Hasil Belajar Siswa Pada Mata Pelajaran Komputer Akuntansi Dengan Menggunakan Media Tutorial Myob Berbasis Adobe Captivate. Journal of Accounting and Business Education, 1(4).

https://doi.org/10.26675/jabe.v1i4.603

8

Ningsih, R., \& Nurrahmah, A. (2016). Pengaruh Kemandirian Belajar Dan Perhatian. Jurnal Formatif, 6(1), 7384.

Nurfadilah, S., \& Hakim, D. L. (2019). Kemandirian Belajar Siswa dalam Pembelajaran Matematika. Prosiding Sesiomadika 2019, 1214-1223. http://journal.unsika.ac.id/index.php/se siomadika

Rijal, S., \& Bachtiar, S. (2015). Hubungan antara Sikap, Kemandirian Belajar, dan Gaya Belajar dengan Hasil Belajar Kognitif Siswa. Jurnal Bioedukatika, $3(2)$, 15. https://doi.org/10.26555/bioedukatika. v3i2.4149

Safitri, M. E., \& Setiyani, R. (2016). Pengaruh Motivasi Belajar, Computer Attitude Dan Fasilitas Laboratorium Akuntansi Terhadap Prestasi Belajar Komputer Akuntansi Myob. Economic Education Analysis Journal, 5(1), 3043. 
PROGRESS

Jurnal Pendidikan, Akuntansi dan Keuangan

Universitas Banten Jaya
Vol 4 No. 2, Agustus 2021

E-ISSN 2622-7037 |P-ISSN 2623-0763 